\title{
Use of Salines Waters and Biofertilizers in Quality of the Seedlings From Passiflora edulis Evaluated by the Dry Phytomass
}

\author{
Francisco de O. Mesquita $\mathrm{II}^{1}$, Ana C. M. Meireles ${ }^{1}$, José L. N. Cardoso ${ }^{1}$, Carlos W. Oliveira ${ }^{1}$ \\ \& Patrycia L. B. Roguides ${ }^{1}$ \\ ${ }^{1}$ Department of Agronomy, Federal University of Cariri, Crato, CE, Brazil \\ Correspondence: Francisco de O. Mesquita II, Department of Agronomy, Federal University of Cariri, CEP: \\ 63.133-520, Crato, CE, Brazil. Tel: 55-889-9943-6685. E-mail: mesquitaagro@yahoo.com.br
}

Received: December 22, 2018

Accepted: February 2, $2019 \quad$ Online Published: April 15, 2019

doi:10.5539/jas.v11n5p121

URL: https://doi.org/10.5539/jas.v11n5p121

\begin{abstract}
The objective of this study was to evaluate the effects of the biofertilizers (common and enriched) in substrate irrigated with saline waters on the quality of the seedlings evaluated by the phytomass from yellow Passiflora edullis. In this sense, an experiment was carried in a greenhouse at the Center of Agricultural Sciences and Biodiversity CCAB/UFCA, Crato-CE, from October/2017 to March/2018. The substrate used was a material of the first $20 \mathrm{~cm}$ to depth of a Red Yellow Latosol. The experimental design was completely randomized in a factorial scheme of type $5 \times 3$, with three replications, referring to the electrical conductivity values of the irrigation water: $0.5 ; 1.0 ; 2.0 ; 3.0$ and $4.0 \mathrm{dS} \mathrm{m}^{-1}$, in the soil without the bovine biofertilizer; in treatments with common biofertilizer and, evaluated in the soil with enriched biofertilizer, conditioned in black polyethylene bags with it a maximum capacity of $5.0 \mathrm{~kg}$, totaling 60 treatments. The fermented bovine biofertilizer after dilution in non-saline and non-chlorinated water $\left(0.5 \mathrm{dS} \mathrm{m}^{-1}\right)$, in the proportion of $1: 3$, was applied only once to $10 \%$ of the substrate volume, two days before sowing. The salinity increase of the irrigation water affected negatively the phytomass production, but with less intensity in the treatments with enriched biofertilizer. The enriched and common biofertilizer provided higher growth and consequently higher phytomass production of passion fruit seedlings in relation to the soil without the respective input, independently of the level of salinity of irrigation water.
\end{abstract}

Keywords: Passiflora edulis F. Flavicarpa Deg, organic input, sanilization

\section{Introduction}

The yellow passion fruit (Passiflora edulis f. Sims, Flavicarpa Deg.), which is also called the sour passion fruit, is a species originated from Tropical America, with more than 150 species native to Brazil, intensely cultivated in countries of tropical and subtropical climate, which corresponds to about $98 \%$ of productivity in Brazil (Agrianual, 2016). For the rural producer small, the passion fruit it's a culture that represents great economic importance, to be it presents a source of profit during the year and because of it your good adaptability for the fruit market in natura (Faleiro, Farias Neto, \& Ribeiro Júnior, 2008; Meletti, 2011; Souza et al., 2018).

In Brazil, the area affected by the saline stress corresponds to $5 \%$ of the total area and $33 \%$ of the world's soils are degraded or in process of erosion, salinization, compaction, acidification and contamination are among the main problems (FAO, 2015). In this case, it contributes to the great obstacle to crop productivity, especially on the Northhest of Brazil or in semi-arid areas around the world, where the irrigation system occurs mainly by sprinkling or drip irrigation and low-quality water. Under high saline conditions, the expansion of these areas naturally compromised, in the irrigated perimeters of the Brazilian Northeast constitutes economic and social disorders to the semi-arid region where the production system depends of irrigation and every day new production areas are installed to attend the growing food demand (Yang et al., 2011; Medeiros et al., 2016).

The rational use of water in irrigated agriculture has been a recurrent discussion along the last decades, especially with respect to water quality (Ayers \& Westcot, 1999; Silva et al., 2007; Anami, Sampaio, Suszek, Gomes, \& Queiroz, 2008). The water use with high salt content results in the salinization of agricultural soils, causing disturbances and altering the chemical nature in these soils, besides to limiting the development of the crops (Mesquita et al., 2015; Sá, Silva, Brito, \& Figueiredo, 2015; Ribeiro, Dantas, Mathias, \& Pelacaci, 2017; Oliveira et al., 2017). 
The saline water has hampered agricultural activity both by the direct effects on the plant and by its accumulation in the superficial layers of the soil. The effects of salinity are related to the decrease of the osmotic potential, reducing the availability of water to the plants, at the toxic effect of specific ions, such as $\mathrm{NaCl}$ ions, and, to the nutritional effect (Epstein \& Bloom, 2006; Munns \& Tester, 2008). The saline stress, according to Silveira et al. (2012), is related to two types of effects: the osmotic and the ionic. The first effects caused by the excess salts are of a biophysical nature, standing out at the osmotic effects, restricting the transport of water. As they saline ions accumulate excessively on the cytosol of the cells will arise toxicity problems (toxic or ionic phase) in the plants exposed to the salinity (Taiz \& Zeiger, 2013).

Currently, grow up the demand by acquisition of high-quality seedlings and with well-defined agronomic parameters and even in the production system of yellow passion fruit seedlings. For the production of good quality seedlings, should be adopted efficient methodologies and, if possible, low cost methodologies (Dutra, Grazziotti, Santana, \& Massad, 2012). However, mainly in arid and semi-arid regions, where the water scarcity has it become a preponderant factor, the production of seedlings is carried out it using ground-water, which in most cases contains high concentrations of soluble salts, impairing the germination and the growth of them (Souza \& Peres, 2016; Oliveira et al., 2017). This inconvenience can transform productive lands into unproductive lands, therefore, it requires the adoption of technologies that either minimize the salinization of the soils with the water management or that allow to produce in areas compromised by salts without large losses of agricultural income and quality of production through the use of organic inputs with positive action on the physical characteristics of the soil and in the root environment of plants (Nascimento, Medeiros, Alves, Lima, \& Silva, 2015; Medeiros et al., 2016).

In this context, arise up the need for adoption of cropping technologies that attenuate the deleterious effects of salts excess in irrigation water during the whole the growing phase of the plants, principally during emergence and seedling formation. Among the technological materials employees, stand out the use biofertilizers of bovine manure (humic substances) where under irrigation with saline water, these inputs provide greater osmotic adjustment between the roots and the soil solution, minimizing the toxic effects of the salts in the plants (Aydin, Kant \& Turan, 2012), increasing thereby the water absorption efficiency and, consequently to stimulate the plant growth (Matsi, Lithourgidis, \& Barbayiannis, 2015; Oliveira et al., 2018). Studies have pointed that the use of bovine biofertilizer applied during the formation of fruit seedlings can attenuate the negative effects of irrigation with saline water (Nascimento et al., 2011).

In this sense, an experiment was conducted in a protected environment, with the objective of evaluating the effects of water salinity of irrigation and biofertilizers types (common and enriched) in substrate assessing the quality of the seedlings evaluated by the phytomass from yellow Passiflora edullis.

\section{Material Studied}

\subsection{Characterization of Area}

This work with yellow passion fruit, cultivate BRS SC1, was conducted in the period from October 2017 to March 2018, in greenhouse (protected environment), in the Center for Agrarian Sciences and Biodiversity (CASB), of the Federal University of Cariri (CCA-UFCA), in county of Crato, CE, Brazil.

The county of Crato is situated at 422 above sea level, situated under the geographical coordinates of latitude $7^{\circ} 23^{\prime 2} 26^{\prime \prime}$ (S) and longitude of $39^{\circ} 36^{\prime} 94^{\prime \prime}$ (W) of Greenwich. According to the classification of Köppen, the region's climate is of type Aw (tropical climate with dry winter season). The county of Crato has average temperature in the order of $25.10{ }^{\circ} \mathrm{C}$. It has an average annual rainfall of $1086 \mathrm{~mm}$, concentrating in the months of January to May, according Köppen and Geiger (Lima, Meireles, Oliveira, \& Nascimento, 2017). The rainy season is concentrated in the period from March to June, with average rainfall of $1.400 \mathrm{~mm}$ per year. The average air temperature is around $23.50^{\circ} \mathrm{C}$.

\subsection{Experimental Design}

The treatments were distributed in a completely randomized design and in factorial scheme $5 \times 3$, with three replicates, referring at the salinity values of irrigation water of $0.5 ; 1.0 ; 2.0 ; 3.0$ and $4.0 \mathrm{dS} \mathrm{m}^{-1}$, in the treatments without biofertilizer + two types of biofertilizer: common biofertilizer and enriched chemically biofertilizer, conditioning in black polyethylene bags with a maximum capacity of $5.0 \mathrm{~kg}$, totaling 60 treatments.

\subsection{Preparation of Salines Waters}

For obtaining of the value of electrical conductivity from each type of water used for irrigation constituted the addition of $\mathrm{NaCl}$ in water from $\mathrm{CCAB} / \mathrm{UFCA}$. In the preparation of the five water treatments with different saline compositions, the water used was from a local pool, of low salinity and without addition of chlorine (ECw 
$\left.=0.28 \mathrm{dS} \mathrm{m}^{-1}\right)$, and after that, was added $\mathrm{NaCl}$ in the preparation of other waters for additional irrigation of 1.0 ; 2.0; 3.0 and $4.0 \mathrm{dS} \mathrm{m}^{-1}$ according proceeded (Mesquita et al., 2015). For the measurements and control of the electrical conductivities of the waters, It utilized a portable digital conductivity, from model Hi98304 manufacturer Hanna.

\subsection{Physical, Chemical and as to Salinity Characterization}

The substrate used was a sandy-textured Argissol Red-yellow, no-saline (Embrapa, 2013), submitted to laboratory analysis to determine the physical and chemical attributes regarding fertility and salinity indicated in Table 1, according to Embrapa (2013) and (Richards, 1954).

Table 1. Physical and chemical characterization of soil as to fertility and salinity in layer of $0-20 \mathrm{~cm}$. Crato-CE, Brazil, 2018

\begin{tabular}{|c|c|c|c|c|c|}
\hline Physical Attributes & Value & Fertility Atributes & Value & Salinity Attributes & Value \\
\hline $\mathrm{SD}\left(\mathrm{g} \mathrm{cm}^{-3}\right)$ & 1.56 & $\mathrm{pH}$ in water $(1: 2.5)$ & 6.78 & $\operatorname{SEEC~}\left(\mathrm{dS} \mathrm{m}^{-1}\right)$ & 0.85 \\
\hline $\mathrm{DP}\left(\mathrm{g} \mathrm{cm}^{-3}\right)$ & 2.73 & $\mathrm{OM}\left(\mathrm{g} \mathrm{Kg}^{-1}\right)$ & 12.98 & $\mathrm{pH}$ & 6.86 \\
\hline $\mathrm{TP}\left(\mathrm{m}^{3} \mathrm{~m}^{-3}\right)$ & 0.48 & $\mathrm{P}\left(\mathrm{mg} \mathrm{dm}^{-3}\right)$ & 21.46 & $\mathrm{Ca}^{2+}\left(\mathrm{mmol}_{\mathrm{c}} \mathrm{L}^{-1}\right)$ & 2.41 \\
\hline Sand $\left(\mathrm{g} \mathrm{kg}^{-1}\right)$ & 849 & $\mathrm{~K}^{+}\left(\mathrm{mg} \mathrm{dm}^{-3}\right)$ & 124 & $\mathrm{Mg}^{2+}\left(\mathrm{mmol}_{\mathrm{c}} \mathrm{L}^{-1}\right)$ & 1.42 \\
\hline Silt $\left(\mathrm{g} \mathrm{kg}^{-1}\right)$ & 66 & $\mathrm{Ca}^{2+}\left(\mathrm{cmol}_{\mathrm{c}} \mathrm{dm}^{-3}\right)$ & 1.44 & $\mathrm{Na}^{+}\left(\mathrm{mmol}_{\mathrm{c}} \mathrm{L}^{-1}\right)$ & 4.42 \\
\hline clay $\left(\mathrm{g} \mathrm{kg}^{-1}\right)$ & 96 & $\mathrm{Mg}^{2+}\left(\mathrm{cmol}_{\mathrm{c}} \mathrm{dm}^{-3}\right)$ & 1.42 & $\mathrm{~K}^{+}\left(\mathrm{mmol}_{\mathrm{c}} \mathrm{L}^{-1}\right)$ & 1.53 \\
\hline $\mathrm{CDW}\left(\mathrm{g} \mathrm{kg}^{-1}\right)$ & 16 & $\mathrm{Na}^{+}\left(\mathrm{cmol}_{\mathrm{c}} \mathrm{dm}^{-3}\right)$ & 0.77 & $\mathrm{Cl}^{-}\left(\mathrm{mmol}_{\mathrm{c}} \mathrm{L}^{-1}\right)$ & 6.61 \\
\hline $\mathrm{DF}(\%)$ & 82.42 & $\mathrm{H}^{+}+\mathrm{Al}^{3+}\left(\mathrm{cmol}_{\mathrm{c}} \mathrm{dm}^{-3}\right)$ & 2.62 & $\mathrm{CO}_{3}{ }^{2-}\left(\mathrm{mmol}_{\mathrm{c}} \mathrm{L}^{-1}\right)$ & - \\
\hline DI $(\%)$ & 13.56 & $\mathrm{Al}^{3+}\left(\mathrm{cmol}_{\mathrm{c}} \mathrm{dm}^{-3}\right)$ & 0.00 & $\mathrm{HCO}_{3}{ }^{-}\left(\mathrm{mmol}_{\mathrm{c}} \mathrm{L}^{-1}\right)$ & 1.85 \\
\hline $\mathrm{U}_{\mathrm{cc}}\left(\mathrm{g} \mathrm{kg}^{-1}\right)$ & 14.43 & $\operatorname{SEB}\left(\mathrm{cmol}_{\mathrm{c}} \mathrm{dm}^{-3}\right)$ & 3.94 & $\mathrm{SO}_{4}{ }^{2-}\left(\mathrm{mmol}_{\mathrm{c}} \mathrm{L}^{-1}\right)$ & 1.14 \\
\hline $\mathrm{U}_{\mathrm{pmp}}\left(\mathrm{g} \mathrm{kg}^{-1}\right)$ & 3.87 & $\operatorname{CEC}\left(\mathrm{cmol}_{\mathrm{c}} \mathrm{dm}^{-3}\right)$ & 6.56 & SAR $\left(\mathrm{mmol} \mathrm{L}^{-1}\right)^{1 / 2}$ & 2.76 \\
\hline $\mathrm{AW}\left(\mathrm{g} \mathrm{kg}^{-1}\right)$ & 6.77 & $\mathrm{~V}(\%)$ & 56.77 & $\operatorname{ESP}(\%)$ & 5.27 \\
\hline
\end{tabular}

Note. $\mathrm{SD}=$ Soil Density; $\mathrm{PD}=$ Particle of Density; $\mathrm{TP}=$ Total porosity; $\mathrm{CDW}=$ Clay dispersed in water; $\mathrm{DF}=$ Degree of flocculation; $D I=$ Dispersion index; $U_{\mathrm{cc}}$ and $U_{\mathrm{pmp}}=$ Respectively, humidity of the soil to the -0.01 and $-1.5 \mathrm{Mpa} ; \mathrm{AW}=$ Available water; $\mathrm{OM}=$ Organic matter; $\mathrm{SEB}=$ Sum of Exchangeable Bases $\left(\mathrm{Na}^{+}+\mathrm{K}^{+}+\mathrm{Ca}^{2+}+\right.$ $\left.\mathrm{Mg}^{2+}\right) ; \mathrm{CEC}=$ Cation exchange capacity $=\mathrm{SB}+\left(\mathrm{H}^{+}+\mathrm{Al}^{3+}\right) ; \mathrm{V} \%=$ Saturation value by bases $(100 \times \mathrm{SB} / \mathrm{CTC})$; $\mathrm{SEEC}=$ Saturation extract electric conductivity; $\mathrm{SAR}=$ Sodium adsorptionRelation $=\mathrm{Na}^{+} \times\left[\left(\mathrm{Ca}^{2+}+\mathrm{Mg}^{2+}\right) / 2\right]^{-1 / 2}$; $\mathrm{ESP}=$ Exchangeable SodiumPercentage $\left(100 \times \mathrm{Na}^{+} / \mathrm{CTC}\right)$.

\subsection{Preparation of the Biofertilizers (Common and Enriched)}

The common biofertilizer it was obtained by the anaerobic fermentation of equales parts of non-saline and non-chlorinated water with fresh bovine manure of the cows in lactating during 30 days (Melo Filho et al., 2017). The enriched biofertilizer was prepared with the same amounts of water and fresh manure as the common biofertilizer, but $2 \mathrm{~L}$ of molasses, $4 \mathrm{~L}$ of bovine milk and $2 \mathrm{~kg}$ of agricultural gypsum were added weekly, in a proportion of 1:2:1. To maintain the system, every 10 days a mixture was made to accelerate the microbial process and facilitate fermentation. For the maintenance of each hermetically sealed system, where the end of a 4 $\mathrm{mm}$ diameter hose was connected to the upper base of the biodigester and the other end immersed in a vessel with water. The agricultural gypsum used contained $26 \% \mathrm{CaO}, 14.7 \% \mathrm{~S}$ and $5 \%$ moisture by matter (Leite, Diniz, Cavalcante, Gheyi, \& Campos, 2010).

\subsection{Chemical Characterization of Water and of the Biofertilizers (Common and Enriched)}

The chemical composition of irrigation water and of the two types of biofertilizers in the liquid form was made using the methodologies suggested by Richards (1954). Before application of the organic input, each type of biofertilizer was diluted in water in the proportion of 1:3, applied once, two days before of the sowing, in the volume equivalent at $10 \%$ of the substrate volume $(3.5 \mathrm{~L})$. The chemical composition of water for irrigation and fertilizers in liquid form are showed in Table 2, this was based on the methodologies suggested by Richards (1954), these analyzes were made in laboratory of analytical central, Federal University of Cariri/Campus of Juazeiro do Norte-CE. 
Table 2. Characterization of irrigation water, of the common and enrichedbiofertilizer with milk, molasses and agricultural gypsum. Crato-CE, Brazil, 2018

\begin{tabular}{llll}
\hline \multirow{2}{*}{ Componentes } & Water & \multicolumn{2}{c}{ Biofertilizer } \\
\cline { 3 - 4 } & & Common & Enriched \\
\hline $\mathrm{EC}\left(\mathrm{dS} \mathrm{m}^{-1}\right)$ & 0.59 & 3.68 & 6.25 \\
$\mathrm{SAR}\left(\mathrm{mmol} \mathrm{L}^{-1}\right)^{1 / 2}$ & 2.63 & 1.53 & 2.30 \\
$\mathrm{Ca}^{2+}\left(\mathrm{mmol}_{\mathrm{c}} \mathrm{L}^{-1}\right)$ & 1.37 & 9.35 & 21.42 \\
$\mathrm{Mg}^{2+}\left(\mathrm{mmol}_{\mathrm{c}} \mathrm{L}^{-1}\right)$ & 0.83 & 7.51 & 14.82 \\
$\mathrm{Na}^{+}\left(\mathrm{mmol}_{\mathrm{c}} \mathrm{L}^{-1}\right)$ & 2.56 & 3.42 & 9.21 \\
$\mathrm{~K}^{+}\left(\mathrm{mmol}_{\mathrm{c}} \mathrm{L}^{-1}\right)$ & 0.19 & 11.54 & 16.41 \\
$\mathrm{Cl}^{-}\left(\mathrm{mmol}_{\mathrm{c}} \mathrm{L}^{-1}\right)$ & 2.28 & 20.12 & 25.92 \\
$\mathrm{HCO}_{3}^{-}\left(\mathrm{mmol}_{\mathrm{c}} \mathrm{L}^{-1}\right)$ & 0.45 & 6.02 & 8.82 \\
$\mathrm{CO}_{3}{ }^{2-}\left(\mathrm{mmol}_{\mathrm{c}} \mathrm{L}^{-1}\right)$ & 0.00 & 0.00 & 0.00 \\
$\mathrm{SO}_{4}{ }^{2-}\left(\mathrm{mmol}_{\mathrm{c}} \mathrm{L}^{-1}\right)$ & 0.76 & 6.18 & 15.32 \\
$\mathrm{Classification}^{-1}$ & $\mathrm{C}_{1} \mathrm{~S}_{1}$ & $\mathrm{C}_{4} \mathrm{~S}_{1}$ & $\mathrm{C}_{4} \mathrm{~S}_{1}$ \\
\hline
\end{tabular}

Note. $\mathrm{EC}=$ Electric conductivity; $\mathrm{SAR}=$ Sodium adsorption ratio $\left.=\mathrm{Na}^{+} \times\left[\left(\mathrm{Ca}^{2+}+\mathrm{Mg}^{2+}\right) / 2\right)\right]^{-1}$.

At the sowing were placed five seeds of the yallow passion fruits in each experimental unit with $93 \%$ viability. At the 15 days after emergence, was done the thinning of the seedlings, maintaining the most vigorous and the irrigation with each saline level was accomplished daily in a volume established according to the water requirement of the culture, ranging from 0.15 to $0.35 \mathrm{~L}$ of water until the end of the experiment, respecting the conditions of the soil field capacity.

\subsection{Variables Analyzed at the End of the Experiment}

At the end of the experiment, at 180 DAE (days after emergence), the following morphological parameters were evaluated: dickson quality index, root length, using a graduated ruler; root area through leaf disc weights proposed by Mielke, Hoffmann, Endres and Fachinello (1995) and Nascimento et al. (2011), using a well with a known area $\left(1.0 \mathrm{~cm}^{2}\right)$, where leaf discs of the basal, medial and apical portions were highlighted. The root area was estimated through the known area of leaves discs (KALD) featured of leaf discs weight (LDW) and total of leaf weight (TLW), all analyzed in analytical balance. The total leaf area was estimated applying the following formula: $\mathrm{AF}=\mathrm{PTF} \times \mathrm{ACD} / \mathrm{PDF}$.

For the quantification of dry matter, the seedlings were cut close to the soil, and soon after, were removed carefully all roots, stems and root. Then, were subjected to the washing process with distilled water for withdrawal of soil excess and dried to remove excess water. The separates parts (root, stem and leaves) was added in a safe place, in the nutrition's laboratory of soil at the UFCA. After, was measured the fresh matter of each one of the plants organs in digital precision balance. Posteriorly, the dry vegetable material (root + leaves) was obtained after oven in kiln-drying with forced air circulation at a temperature of $65^{\circ} \mathrm{C}$ up to constant matter. After the drying, was obtained dry matter in digital electronic balance with of $0.01 \mathrm{~g}$.

The morphological parameters of the seedlings and their relationships used in the evaluating the results were: height of aerial part (HAP), stem diameter (SD), total dry matter (TDM), dry matter of aerial part (DMAP), dry matter of roots (DMR), relation between the height of aerial part and dry matter of aerial part, relation between dry matter of aerial part (DMAP) and dry matter of root (DBR) and dickson quality index (DQI), as it also proceeded Mesquita et al. (2015), in Indian neem seedlings (Azadiracta indica A. Juss), Marana, Miglioranza \& Fonseca (2015) in the seedlings of Jaracatiá (Jacaratia spinosa) and Silva et al. (2018) in the culture of the yallow passion fruits (Passiflora edullis L.).

With the datas obtained from dry matter, it was calculated the dry matter of aerial part and total, the relation height of aerial part/collector diameter, the relation between height of aerial part/production of dry matter of aerial part, the relationship between the production dry matter of root/production of dry matter of arerial part its has a variable that measures the quality of seedlings for the field, called of dickson quality index (DQI) according with (Dickson, Leal, \& Hosner, 1960):

$$
\mathrm{DQI}=\frac{\mathrm{DTMP}}{\frac{\mathrm{HP}}{\mathrm{SD}}+\frac{\text { RDMP }}{\text { PADMP }}}
$$

Where, DTMP = Total dry matter production $(\mathrm{g}) ; \mathrm{HP}=$ Height of the aerial part $(\mathrm{cm}) ; \mathrm{SD}=\mathrm{Stem}$ diameter $(\mathrm{mm})$; $\mathrm{RDMP}=$ Root dry matter production $(\mathrm{g})$; PADMP $=$ Part aerea of dry matter production $(\mathrm{g})$. 
The dickson quality index is mentioned as an promising integrated morphological measure and indicated as a good indicator of the seedlings quality, considering for its calculation, the robustness and the balance of the phytomass distribution, being weighted several important parameters (Lisboa et al., 2014).

\subsection{Statistical Analysis}

The results were submitted to analysis of variance by the "F" test, and when significant, the salinity levels of the water were submitted to the Polynomial Regression analysis, while the biofertilizers and the yellow passion fruits were compared by the Tukey $(p<0.05)$ (Banzatto \& Kronka, 2008). For the data processing, the free version of the SISVAR software was used 5.6, Build 86-DEX-UFL Alivre (Ferreira, 2011).

\section{Results and Discussion}

The statistical analysis revealed significant effects of the interaction of water salinity and biofertilizers on root length and root area of the yellow passion fruit, indicating that the actions of these independent factors exerted positive effects on the growth and development of this Passifloraceae (Figure 1).

In the absence of biofertilizer $(\bullet)$,the substrates of the yellow passion fruit seedlings had their root length increased from 13.40 to up $18.14 \mathrm{~cm}$ in the salinity threshold of $1.96 \mathrm{dS} \mathrm{m}^{-1}$ (Figure 1A). This behavior of the seedlings may be related to the process of inhibition of the root system as a strategy to avoid direct contact of the deleterious effect of the salts. According to Taiz et al. (2017), this inhibition of the growth caused by the salinity is due to the osmotic effect, which promotes the physiological drought, as well as causes the toxic effect, resulting from the concentration of ions in the protoplasm.
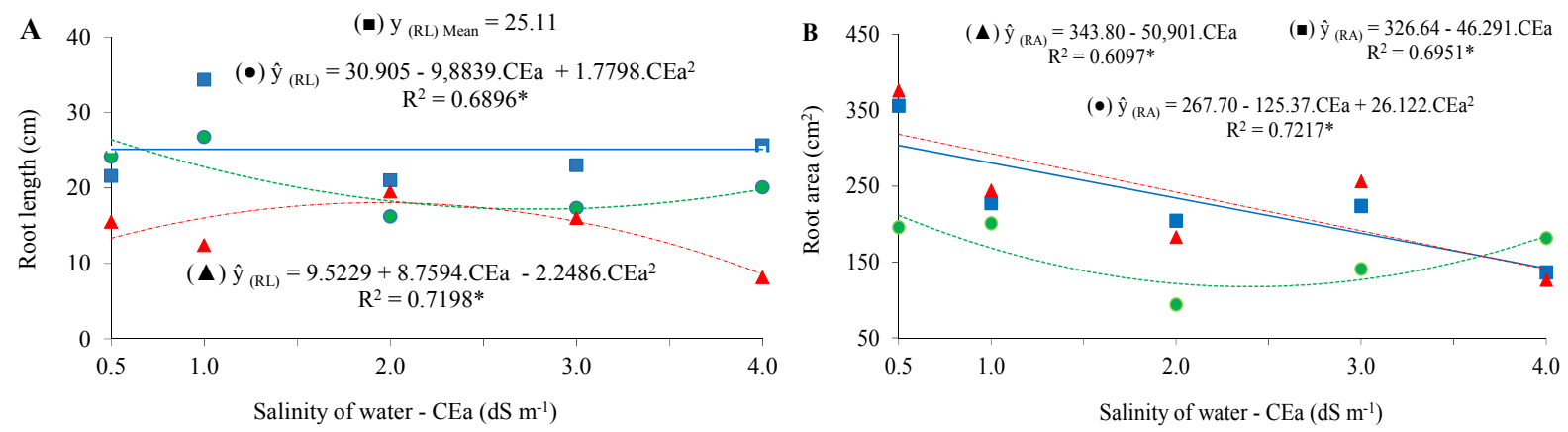

Figure 1. Root length (A) and root area (B) of passion fruit seedlings evaluated on the substrate without bovine biofertilizer $(\bullet)$, with common biofertilizer $(\boldsymbol{\bullet})$ and with enriched biofertilizer $(\boldsymbol{\Lambda})$ in function of the salinity of irrigation water. Crato-CE, 2018

Because, the salinity tolerance, either even so relatively low in the majority of the cultivated species, can occur with great genetic variability not only among species, but also among cultivars within a species such as that occurring in this study (Ponte et al., 2011).

Analyzing the root length of the seedlings in the soil with common biofertilizer ( $\mathbf{m})$, this variables response were reduced with the increase of electrical conductivity of water $(\mathrm{ECw})$, where it was observed that as you increased the $\mathrm{ECw}$, there was a unit decrease of $3.61 ; 4.57$ and $1.03 \mathrm{~cm}$ for each value unit of the electrical conductivity of the irrigation water, evaluated at $180 \mathrm{DAE}$, respectively (Figure 1A).

This reduction in the root system is due to the direct effects of the ions toxicity or indirect effects of the saline ions present in the soil, causing osmotic imbalances to plants (García, Alcántara, \& Fernández, 2011). These data's in consonance with Cavalcante et al. (2010) verified that the excess of sodium salts entails a series of losses in the chemical and physical properties of the soil, whereas consequently, causes the reduction in the growth and in some situations the death of the cultivated plants.

The increase of the water salinity levels reduced the growth of root length during the formation of the yellow passion fruit seedlings, restricting independently of the application of organic inputs (common and enriched), but with superiority to the treatments that received the enriched organic input provided before sowing (Figure 1A).

Although the dispersion high of the datas, in function of the stress caused by the salinity of the waters, the enriched biofertilizer ( $\mathbf{\Lambda}$ ) did not adjust the none them mathematical model, but, even so, it promoted a longer root length of the seedlings in relation to the soil without and with a common organic input, respectively, with 
average value of $25.11 \mathrm{~cm}$. These datas are in accordance with Cavalcante et al. (2009), who verified superiority in the root development of yellow passion fruit seedlings on substrate fertigated with biofertilizer ( $\mathbf{a})$ and irrigated with saline waters.

The root area of the seedlings of passion fruits suffered with the increase of ECw, where it was observed that as you increased the ECw, there was a percentage loss of 15.08, 114.51 and 127.06\%, at 180 DAE (Figure 1B), of the seedlings of passion fruits treated without the organic input, with common and enriched biofertilizer, respectively. The greater expansion root of plants in the soil with biofertilizer ( $\mathbf{a})$, is generally, is a response to the better physical condition provided to the substrate by the humus substances (Abdel-Latef et al., 2011), as well as, at the higher accumulation of organic solutes such as soluble carbohydrates and other substances as proline in the plants raising the capacity of osmotic adjustment (Sucre et al., 2011).

The energy spent by the plant to absorb water in a saline soil is higher than that to absorb water from a solution without salts. This reduction in the leaf area development in relation to root growth would reduce the plant's water use, thus allowing a higher concentration of salts in the soil, damaging the metabolic activities of plants (Taiz \& Zeiger, 2013). According to Taiz et al. (2017), this inhibition of the growth caused by the salinity is due to the osmotic effect, which promotes the physiological drought, as well as causes the toxic effect, resulting from the concentration of ions in the protoplasm.

It was observed that the increase in ECw effects exercised significant on the dickson quality index (DQI) and, according with to the regression equation, the model to which the datas had or presented better adjustments in $\mathrm{R}^{2}$, that is, adjusted was quadratic in all situations studied. The irrigation with water up to $4.0 \mathrm{dS} \mathrm{m}^{-1}$ reduced quadratically, the diskson quality index, reaching the lowest value of 0.67 , which corresponded to a decrease of $163.43 \%$, per unit increase in ECw to salinity threshold of $2.28 \mathrm{dS} \mathrm{m}^{-1}$, in the soil without the organic input (Figure 2A). These data are lower than those presented by Melo Filho et al. (2017), when studying the quality index of dickson of Pitomba seedlings (Talisia esculenta) under different electrical conductivities of irrigation water. These authors verified a drastic percentage drop of up to $173.17 \%$ dickson quality index of these seedlings in the salinity threshold of $4.5 \mathrm{dS} \mathrm{m}^{-1}$.

According to the criterion of Hunt et al. (1990), the DQI less than 0.2 indicates seedlings not considered of good final quality to be established in the field and the higher the DQI value, better will be the seedling quality. In this sense, the treatments that did not receive the fermented organic compound with the lowest dickson quality index (DQI) in the order of 0.67 , at the threshold salinity of $2.28 \mathrm{dS} \mathrm{m}^{-1}$, the yellow passion fruit seedlings are with superior quality suitable for the transplanting, demonstrating robustness and performance in the field. The tendency of the plants to increase their yields after the minimum point would be a biological natural response of the plants against the adversity or saline stress, in the saline environment.
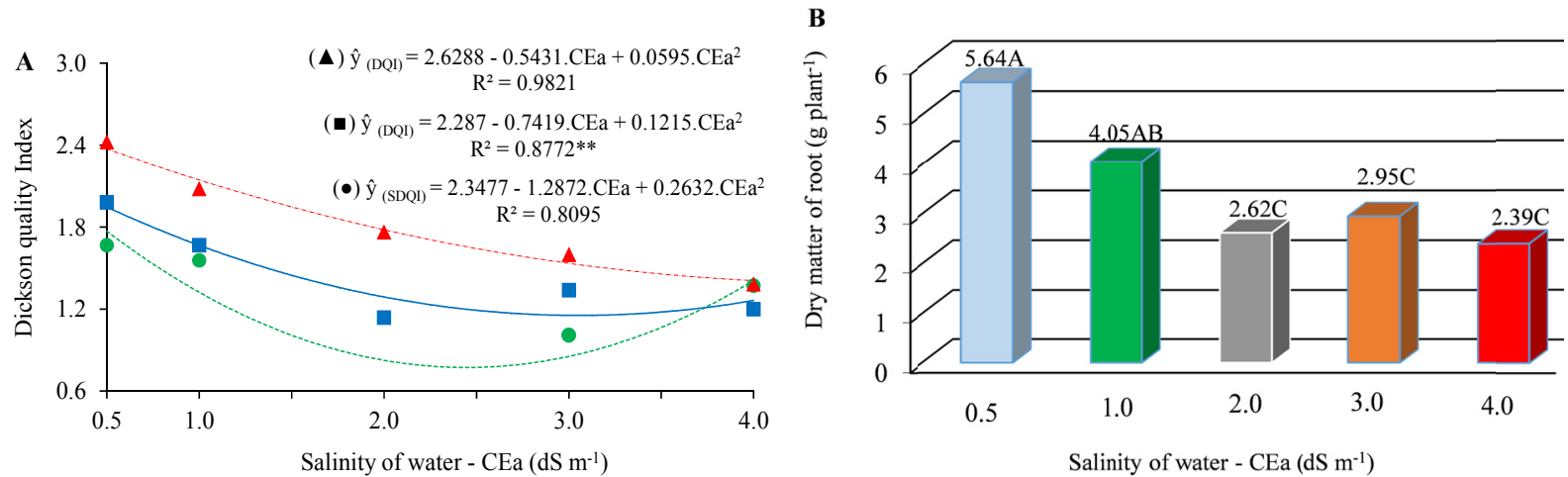

Figure 2. Dickson quality Index (A) and dry matter of root (B) of the yellow passion fruit seedlings treated in the soil without bovine biofertilizer $(\bullet)$, in the presence of common biofertilizer $(\boldsymbol{\square})$ and with enriched biofertilizer

( $\Delta$ ) to the detriment of the salinity of irrigation water. Crato-CE, 2018

When comparing the values of the dickson quality index (DQI) for the soil with common and enriched biofertilizers (Figure 2A), Its note a superiority expressive in the behavior of the seedlings, however, the drastic inhibition of the plants caused by the salts was reported in all situations, except in the treatments with common organic compound (ש), as of the threshold salinity $3.0 \mathrm{dS} \mathrm{m}^{-1}$, that is, the saline stress reduced significantly the quality of the seedlings evaluated by the DQI parameter 2.36 to 1.53 ( 0.5 and $4.0 \mathrm{dS} \mathrm{m}^{-1}$, respectively) due to the 
direct effects of ionic ions or indirect effects of the saline ions present in the soil, causing osmotic imbalances to the plants (García, Alcántara, \& Fernández, 2011). These datas are superior to those presented by Mesquita et al. (2015), verified that the excess of sodium salts entails a series of losses in the chemical and physical properties of the soil, which, consequently, causes a percentage reduction of $83.34 \%$ in the growth and quality of the neem seedlings (Azadirachta indica).

By Figure 2A, the model to which the datas referring to the dickson quality index if adjusted in the treatments with enriched biofertilizer $(\boldsymbol{\Delta})$ was the quadratic model, with $\mathrm{R}^{2}$ equivalent to $87.22 \%$, indicating a decrease in the quality of the seedlings through the process of inhibition in the order of 1.94 to $1.13\left(0.5\right.$ and $4.0 \mathrm{dS} \mathrm{m} \mathrm{m}^{-1}$, respectively), due to direct effects of ionic ions or indirect effects of saline ions present in the soil, causing osmotic imbalances to plants (García, Alcántara, \& Fernández, 2011).

Carneiro et al. (2007) confirmed that the height of the aerial part combined with the diameter of the collection is one of the most important morphological parameters to estimate the growth of seedlings after the final planting in the field. Mesquita et al. (2015) working with neem seedlings (Azadirachta indica) and Diniz Neto et al. (2014) evaluating Oiticica seedlings (Licania rigida Benth.), Also observed that high salinity levels decrease the DQI of this plant.

Based in the (Figure 2B), the results of the root dry matter of the passion fruit seedlings, were not statistically significant for the interaction effect type the salinity $\times$ biofertilizers. However, the seedlings succeeded catch up the mean values of 5.64 and 4.05 grams of root dry matter, at the lowest salinity levels, 0.5 and $1.0 \mathrm{dS} \mathrm{m}$, respectively.

When the sodium content is high in relation to the other cations, it can be adsorbed by the exchange complex and, in this case, the clay particles can be dispersed, and the soil loses its structure, becoming impermeable (Holanda Filho et al., 2011). Thus, the dissolved salts in the soil solution promote changes in the physiological processes of the cultures, with consequent reduction in their root growth and their production of photoassimilates.

The highest gains in dry matter of area part (DMAP) and total dry matter (TDM) were obtained in seedlings irrigated with water of lower salinity $\left(0.5 \mathrm{dS} \mathrm{m}^{-1}\right)$ with $19.81 \mathrm{~g}$ (DMAP) and $25.22 \mathrm{~g}$ (TDM) and lower gain in matter in saline irrigation of $4.0 \mathrm{dS} \mathrm{m}^{-1} 6.44 \mathrm{~g}$ (DMAP) and $7.61 \mathrm{~g}$ (TDM). The ECw negatively influenced aerial dry matter (DMAP) and total dry matter (TDM) of the yellow passion fruit seedlings, according to the regression equation (Figure 3). This can be explained by the fact that the $\mathrm{NaCl}$ negatively affects the synthesis and translocation of hormones from roots to the part aere, which results in loss of dry matter (Melo Filho et al., 2017). This response of the plants at saline stress may be a protection response of the plants after this behavior or saline stress.
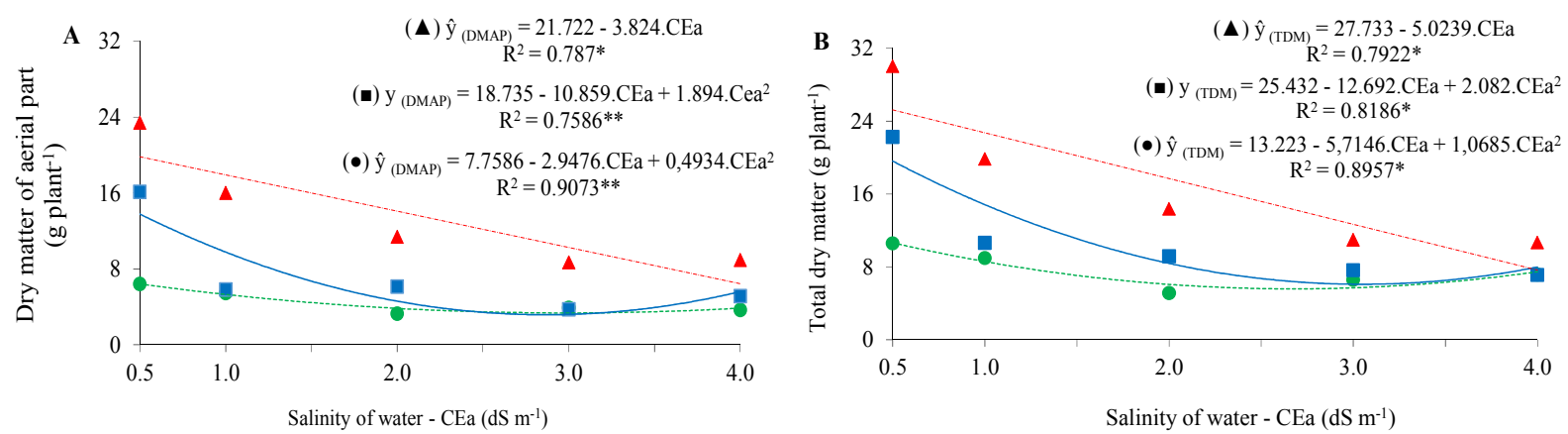

Figure 3. Dry matter of part area (DBPA) and total dry matter (TDB) of the yellow passion fruit seedlings evaluated on the substrate without bovine biofertilizer $(\bullet)$, in the presence of common biofertilizer ( $\mathbf{\square})$ and with enriched biofertilizer $(\boldsymbol{\Delta})$ in function of the salinity of irrigation water. Crato-CE, 2018

The sodium excess favors the nutritional imbalance, triggering toxicity, which affects morphological processes (growth, root expansion) and physiological (respiration, $\mathrm{CO}_{2}$ fixation), resulting in lower growth rate and matter allocation (Cavalcante et al., 2010).

The salinity affected the growth of the seedlings, especially in the initial phase of growth, as observed in yellow passion fruit seedlings (Mesquita, Rebequi, Cavalcante, \& Souto, 2012), papaya (Sá, Silva, Brito, \& Figueiredo, 2015) and oiticica (Diniz Neto et al., 2014). This is due to the fact that the saline stress limits the photosynthetic 
rate and the stomatal conductance, which consequently decreases the rate of $\mathrm{CO}_{2}$ assimilation, compromising plant growth (Freire et al., 2014; Melo Filho et al., 2017).

\section{Conclusions}

The irrigation with saline waters affected the morphology and quality of the yellow passion fruit seedlings (Passiflora edullis), there is, the length of the root and leaf area of the yellow passion fruit seedlings were higher in the substrates with the enriched biofertilizer.

The enriched biofertilizer has a positive action in reducing of the deleterious effects of irrigation saline water in relation to the soil with common input and in the treatments without the organic compound, thus providing, more vigorous yellow passion fruit seedlings.

Evaluating the growth and development of seedlings, both biofertilizers attenuated and provided greater phytomass production and seedling quality.

\section{Acknowledgements}

The authors thank at the National Council for Technological Development Scientific (CNPq), the Higher Education Personnel Coordination (CAPES) and the Science Technology in Salinity National Institute (INCTSal), respectively, for the awarding of scientific initiation scholarships in undergraduate, postgraduate Master's degree, $\mathrm{PhD}$ and research productivity and financial aid to carry out the project activities.

\section{References}

Abdel-Latef, A. A. H., \& Chaoxinh, H. (2011). Effect of arbuscular mycorrhizal fungi on growth, mineral nutrition, antioxidant. Science Horticulture, 127(1), 228-233. https://doi.org/10.1016/j.scienta.2010.09.020

Agrianual. (2016). Brazilian Agriculture Directory (p. 456). São Paulo: Fnp Consultoria \& Agroinformativo.

Anami, M. H., Sampaio, S. C., Suszek, M., Gomes, S. D., \& Queiroz, M. M. F. (2008). Miscible displacement of nitrate and phosphate from swine wastewater in soil columns. Revista Brasileira de Engenharia Agrícola e Ambiental, 12(1), 75-80. https://doi.org/10.1590/S1415-43662008000100011

Aydin, A., \& Kant, C., Turan, M. (2012). Humic acid application alleviate salinity stress of bean (Phaseolus vulgaris L.) plants decreasing membrane leakage. African Journal of Agricultural Research, 7(7), 1073-1086. https://doi.org/10.5897/AJAR10.274

Ayers, R. S., \& Westcot, D. W. A. (1999). Water quality in agriculture (2nd ed., p. 153). Campina Grande: UFPB. https://doi.org/10.1016/S0378-3774(99)00025-6

Banzatto, D. A., \& Kronka, S. N. (2008). Agricultural Experimentation (4th ed., p. 247). Jaboticabal: UNESP.

Carneiro, J. G. A., Barroso, D. G., \& Soares, L. M. S. (2007). Growth of bare root seedlings of Pinus taeda, L., under five spacings in the nursery and their performance in the field. Brazilian Journal of Agro-science, 13, 305-310.

Cavalcante, L. F., Nascimento, J. A. M., Cordeiro, J. C., \& Calvalcante, I. (2010). Sources and levels of water salinity in the formation of papaya seedlings cv. Sunrise solo. Semina: Ciências Agrárias, 31(1), 1281-1290.

Cavalcante, L. F., Silva, G. F., Gleyi, H. R., Dias, T. J., Alves, J. C., \& Costa, A. P. M. (2009). Growth of yellow passion fruit seedlings in saline soil with fermented liquid bovine manure. Brazilian Journal of Agricultural Sciences, 4(4), 414-420.

Dickson, A., Leaf, A. L., \& Hosner, J. F. (1960). Quality appraisal of white spruce and white pine seedling stock in nurseries. Forestry Chronicle, 36(1), 10-13. https://doi.org/10.5558/tfc36010-1

Diniz Neto, M. A., Silva, I. F., Cavalcante, L. F., Diniz, B. L. M. T., Silva, J. C. A., \& Silva, E. C. (2014). Oiticica seedlings irrigated with salt water in the soil with bovine and potassium biofertilizer. Brazilian Journal of Agricultural and Environmental Engineering, 18(1), 10-18.

Dutra, T. R., Grazziotti, P. H., Santana, R. C., \& Massad, M. D. (2012). Initial development of copaiba seedlings under different levels of shading and substrates. Agronomic Science Journal, 43(2), 321-329.

Embrapa (Brazilian Agricultural Research Corporation). (2013). Solos: Brazilian Soil Classification System (3rd ed.). Rio de Janeiro, RJ.

Epstein, E., \& Bloom, A. J. (2006). Mineral nutrition of plants: principles and perspectives (p. 403). Londrina: Editora Planta. 
Faleiro, F. G., Farias Neto, A. L., \& Ribeiro Júnior, W. Q. (2008). Pre-improvement, improvement and post-improvement: Strategies and challenges (1st ed.). Planaltina, Embrapa Cerrados.

Ferreira, D. F. (2011). Sisvar: A computer statistical analysis system. Ciência e Agrotecnologia, 35, 1039-1042. https://doi.org/10.1590/S1413-70542011000600001

FAO (Food and Agriculture Organization of the United Nations). (2015). Intergovernmental technical panel on soils. Status of the World's Soil Resources: Main Report (p. 608). Roma: FAO.

Freire, J. L. O., Cavalcante, L. F., Rebequi, A. M., Dias, T. J., Brehm, M. A. S., \& Santos, J. B. (2014). Quality of yellow passion fruit juice with cultivation using different organic sources and saline water. Idesia, 32(1), 79-87. https://doi.org/10.4067/S0718-34292014000100009

García, B. L., Alcántara, L. P., \& Fernández, J. L. M. (2011). Soil tillage effects on monovalent cations $\left(\mathrm{Na}^{+}\right.$and $\mathrm{K}^{+}$) in vertisols soil solution. Catena, 84(1), 61-69. https://doi.org/10.1016/j.catena.2010.09.005

Holanda Filho, R. S. F., Santos, D. B., Azevedo, C. A. V., Coelho, E. F., \& Lima, V. L. A. (2011). Saline water in soil chemical attributes and nutritional status of cassava. Brazilian Journal of Agricultural and Environmental Engineering, 15(1), 60-66.

Hunt, G. A. (1990). Effect of styroblock design and cooper treatment on morphology of conifer seedlings. Proceedings of Target seedling symposium, meeting of the western forest nursery associations, general technichal report RM-200, 1990, Roseburg (pp. 218-222). Fort Collins: United States Departament of Agriculture, Forest Service.

Leite, E. M., Diniz, A. A., Cavalcante, L. F., Gheyi, H. R., \& Campos, V. B. (2010). Reduction of sodicity in an irrigated soil with the use of sulfuric acid and agricultural gypsum. Journal Caatinga, 23(2), 110-116.

Lima, M. T. V., Meireles, A. C. M., Oliveira, C. W., \& Nascimento, M. T. B. (2017). Koppen-Geiger and Thornthwaite climatic classification for the metropolitan region of the Cariri, Ceará. Revista Geama, 3(3), 136-143.

Lisboa, A. C., Melo Júnior, C. J. A. H., Tavares, F. P. A., Almeida, R. B., Melo, L. A., \& Magistralli, I. C. (2014). Crescimento e qualidade de mudas de Handroanthus heptaphyllus em substrato com esterco bovino. Pesquisa Florestal Brasileira, 38(1), 1-6.

Marana, J. P., Miglioranza, E., \& Fonseca, E. P. (2015). Quality of jaracatiá seedlings submitted to different shading periods in nursery. Journal Tree, 39(2), 275-282.

Matsi, T. H., Lithourgidis, A. S., \& Barbayiannis, N. (2015). Effect o fliquid cattle manure on soil chemical properties and corn growth in Northern Greece. Experimental Agriculture, 51(1), 435-450. https://doi.org/ $10.1017 / \mathrm{S} 0014479714000404$

Medeiros, S. A. S., Cavalcante, L. F., Bezerra, M. A. F., Nascimento, J. A. M., Bezerra, F. T. C., \& Prazeres, S. S. (2016). Saline water and bovine biofertilizer of manure in the formation and quality of yellow passion fruit seedlings. Irriga, 21(4), 779-795. https://doi.org/10.15809/irriga.2016v21n4p779-795

Meletti, L. M. M. (2011). Advances in passion fruit culture in Brazil. Brazilian Journal of Fruticulture, 33(1), 83-91.

Melo Filho, J. S., Veras, M. L. M., Alvez, L. S., Silva, T. I., Gonçalves, A. C. M., \& Dias, T. J. (2017). Water salinity, bovine biofertilizer and dead plant cover in the production of pitombeira seedlings (Talisia esculenta). Revista Scientia Agraria, 18(3), 131-145.

Mesquita, F. O., Nunes, J. C., Lima Neto, A. J., Luna Souto, A. G., Batista, R. O., \& Cavalcante, L. F. (2015). Formation of neem seedlings under water salinity, biofertilizer and soil drainage. Irriga, 20(2), 193-203. https://doi.org/10.15809/irriga.2015v20n2p193

Mesquita, F. O., Rebequi, A. M., Cavalcante, L. F., \& Souto, A. G. D. L. (2012). Absolute and relative growth of passion fruit seedlings under biofertilizer and salt water. Journal of Agricultural Sciences, 35(1), 222-239.

Mielke, M. S., Hoffmann, A., Endres, L., \& Fachinello, J. C. (1995). Comparação de métodos de laboratório e de campo para a estimativa da área foliar em fruteiras silvestres. Science Agriculture, 52(1), 85-88. https://doi.org/10.1590/S0103-90161995000100015

Munns, R., \& Tester, M. (2008). Mechanisms of Salinity Tolerance. Annual Review of Plant Biology, 59, 651-681. https://doi.org/10.1146/annurev.arplant.59.032607.092911 
Nascimento, I. B., Medeiros, J. F., Alves, S. S. V., Lima, B. L. C., \& Silva, J. L. A. (2015). Initial development of pepper culture influenced by salinity of irrigation water in two types of soils. Agropecuária Cientifica no Semiárido, 11(1), 37-43.

Nascimento, J. A. M., Cavalcante, L. F., Santos, P. D., Silva, S. A., Vieira, M. S., \& Oliveira, A. P. (2011). Effect of the use of bovine biofertilizer on the production of pepper plants irrigated with saline water. Revista Brasileira de Ciências Agrárias, 6(2), 258-264. https://doi.org/10.5039/agraria.v6i2a1069

Oliveira, F. I. F., Luna Souto, A. G., Cavalcante, L. F., Medeiros, W. J. F., Bezerra, F. T. C., \& Bezerra, M. A. F. (2017). Quality of jackfruit seedlings under saline water stress and nitrogen fertilisation. Semina: Ciências Agrárias, 38(4), 2337-2350. https://doi.org/10.5433/1679-0359.2017v38n4SUPLp2337

Oliveira, F. I. F., Luna Souto, A. G., Cavalcante, L. F., Medeiros, W. J. F., Medeiros, S. A. S., \& Oliveira, F. F. (2018). Biomass and chloroplast pigments in jackfruit seedlings under saline stress and nitrogen fertilization. Revista Caatinga, 31(3), 622-631. https://doi.org/10.1590/1983-21252018v31n310rc

Ponte, L. F. A., Ferreira, O. S., Alves, F. A. L., Ferreira-Silva, S. L., Pereira, V. L. A., \& Silveira, J. A. G. (2011) Variability of physiological indicators of salinity resistance between dwarf cashew and giant genotypes. Pesquisa Agropecuária Brasileira, 46(1), 1-8. https://doi.org/10.1590/S0100-204X2011000100001

Ribeiro, R. C., Dantas, B. F., Matias, J. R., \& Pelacaci, C. R. (2017). Effect of saline stress on germination and initial seedling growth of Erythrina velutina Willd. (Fabaceae). Gaia Scientia, 11(4), 65-78. https://doi.org/10.22478/ufpb.1981-1268.2017v11n4.35471

Richards, L. A. (1954). Diagnosis and Improvement of Saline Alkali Soils, Agriculture, 160, Handbook 60. US Department of Agriculture, Washington DC.

Sá, F. V. S., Silva, L. A., Brito, M. E. B., \& Figueiredo, L. C. (2015). Physiology of the perception of saline stress in mandarin hybrids-Sunki Comum under salinized hydroponic solution. Comunicata Scientiae, 6(1), 463-470. https://doi.org/10.14295/cs.v6i4.1121

Silva, A. F., Pinto, J. M., França, C. R. R. S., Fernandes, S. C., Gomes, T. C. A., Silva, M. S. L., \& Matos, A. N. B. (2007). Preparation and use of liquid biofertilizers. Technical Communication (p. 4). Petrolina.

Silva, N. M., Sousa, L. G., Uchôa, T. L., Almeida, W. A., Araujo Neto, S. E., \& Ferreira, R. L. F. (2018). Quality of yellow passion fruit seedlings produced with alternative substrates. Agropecuária Científica no Semiárido, 14(2), 96-102.

Silveira, J. A. G., Melo Júnior, J., Silva, E. N., Ferreira-Silva, S. L., Aragão, R. M., \& Viégas, R. A. (2012). Salt resistance in two cashew species is associated with accumulation of organic and inorganic solutes. Acta Physiologiae Plantarum, 34(5), 1629-1637. https://doi.org/10.1007/s11738-012-0957-3

Souza, L. K. F., Pereira, L. D., Valle, K. D., Paiva, E. F., Bolina, C. C., Reis, E. F., ... Silva, D. F. P. (2018). Growth and development of three species of passion fruit in southwestern Goiania. Revista Brasileira de Agropecuária Sustentável, 8(1), 24-29.

Souza, L. R., \& Peres, F. S. B. (2016). Use of biofertilizers based on amino acids in the production of seedlings of Eucalyptus dunnii. Pesquisa Florestal Brasileira, 36(87), 211-218. https://doi.org/10.4336/2016.pfb. 36.87 .1127

Sucre, B., \& Suáres, N. (2011). Effect of salinity and PEGinduced water stress on water status, gas exchange, solute accumulation, and leaf growth in Ipomoea pes-caprae. Environmental and Experimental Botany, 70(1), 192-203.

Taiz, L., \& Zeiger, E. (2013). Plant Physiology (5th ed., p. 954). Porto Alegre: Artemed.

Taiz, L., Zeiger, E., Moller, I. M., \& Murphy, A. (2017). Plant Physiology (6th ed., p. 818). Porto Alegre: Artmed.

Yang, J., Dungrawala, H., Hua, H., Manukyan, A., Abraham, L., Lane, W., ... Schneider, B. L. (2011). Cell size and growth rate are major determinants of replicative lifespan. Cell Cycle, 10(1), 144-55. https://doi.org/ $10.4161 / \mathrm{cc} \cdot 10.1 .14455$

\section{Copyrights}

Copyright for this article is retained by the author(s), with first publication rights granted to the journal.

This is an open-access article distributed under the terms and conditions of the Creative Commons Attribution license (http://creativecommons.org/licenses/by/4.0/). 